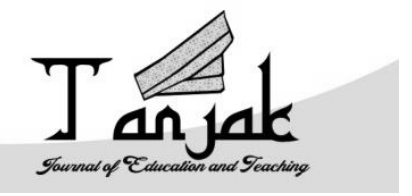

\author{
Tanjak: Journal of Education and Teaching \\ ISSN 2716-4098 (P) 2720-8966 (O) \\ Volume 1 Nomor 2, 2020
}

\title{
The Effect of Playing Online Vocabulary Games and Motivation on Student's Vocabulary Mastery in Insan Utama Junior High School Pekanbaru
}

\author{
Herlianisyah Lubis
}

Universitas Islam Negeri Sultan Syarif Kasim Riau, Pekanbaru, herlianisyahlubis680@gmail.com

DOI: https://doi.org/10.35961/tanjak.v1i2.122

\begin{abstract}
Abstrak
Pentingnya penguasaan kosakata memberikan komunikasi yang baik antara siswa dan guru di dalam kelas dan pembelajaran aktif. Tanpa kosa kata tidak mungkin menggunakan bahasa Inggris sebagai komunikasi Burton, dan kosa kata jumlah total kata yang menyusun bahasa, menguasai pola tata bahasa dasar bahasa Hornby. Dalam kaitannya dengan ide-ide teoritis, kosakata merupakan faktor kunci untuk memastikan bahwa produksi (kosakata reseptif dan kosakata produktif) untuk mendapatkan kosakata sebagai faktor kunci perlu adanya motivasi dalam proses pembelajaran. Dengan bermain game online diharapkan siswa memiliki motivasi dalam belajar bahasa asing khususnya mata pelajaran bahasa inggris. Bermain game online bisa membuat santai siswa karena pembelajar muda menyukai game. Berdasarkan Ashraf (2014: 290), gamer semakin tertarik untuk bermain online dan ingin mendapatkan hasil yang lebih baik. Siswa lebih interaktif dan memotivasi serta efektif dalam kosakata. Merupakan alasan peneliti untuk memilih game online untuk meningkatkan motivasi siswa dan menambah kosa kata siswa. Pembelajaran memiliki pengaruh dan perubahan yang signifikan bagi pembelajaran, motivasi dan kosa kata siswa.
\end{abstract}

Kata Kunci: Game Online, Penguasaan Kata, Motivasi

Tanjak: Jounal of Education and Teaching, Vol. 1, No. 2, 2020 


\section{Abstract}

The importance of vocabulary mastery given communicate well between students and teacher in the classroom and learning active. Without vocabulary impossible use English language as communication Burton, and vocabulary total number of the word making up the language, master the fundamental grammatical pattern of language Hornby. In relation to the theoretical ideas, vocabulary is the key factor to ensure that production (receptive vocabulary and productive vocabulary) to get vocabulary as the key factor need a motivation in proces learning. With playing online game it is hoped students have a motivation in learning foreign language especially English subject. Playing online game can relax for students because young learners like games. Based on Ashraf (2014:290), gamers became more intersted in playing online and wished to achieve better result. Students more interactive and motivating and effective in vocabulary. It is the researchers' reasone to choose online game for up grading students motivation and increase students' vocabulary. Study got significant impact and change for the students learning, motivation and vocabulary.

Keywords: Online Game, Vocabulary Mastery, Motivation

\section{Introduction}

The importance of vocabulary mastery given communicate well between students and teacher in the classroom and learning active. Without vocabulary impossible use English language as communication Burton (1982:98) and vocabulary total number of the word making up the language, master the fundamental grammatical pattern of language Hornby (1994:959)

It means that students who do not learn and master the language cannot communicative well and master the fundamental grammatical pattern. Students Insan Utama islamic junior high school got some problems in vocabulary. First, students hard to understand the meaning of the text/word, sometimes students skip the word / text when students found unknown meaning, lack of vocabulary and background knowledge of vocabulary.

Secondly, the students also had difficulties to use appropriate choice of the words, cannot use grammatically, did not know about word information ( noun, adverb, adjective, and verb) some of students confused, part of speech, synonym, antonym, confused word meaning and finding out the unfamiliar words when they are reading and some of students not interesting in English Subject. Based on the background problems also come from students self.

And the third is motivation, it is related to the students' interest in learning. Students who are highly motivated to learn something are more likely to be active than others to consciously plan their learning motivated students usually want to understand the content of the text fully and process learning (Slavin,2009:302) and motivation one of factor given place as well as cognitive process in learning process Warg and Guthrie (2004).

It is not easy to mastering vocabulary, based on the table below students might lack of vocabulary / unknown meaning of the word. Researcher found students' score on answer sheet of several question in basic competence of sub topic

Table 1. The English vocabulary score at seven grade of Insan Utama

\begin{tabular}{|l|c|c|c|c|c|}
\hline & Academic & & \multicolumn{2}{|c|}{} & \\
\cline { 4 - 6 } No. & year & Class & \multicolumn{2}{|c|}{ Students score } & Total \\
\hline & & & $>75$ & $<75$ & \\
\hline
\end{tabular}




\begin{tabular}{|c|c|c|c|c|c|}
\hline 1 & $2019 / 2020$ & VII.1 & 6 & 9 & 15 \\
\hline 2 & & VII.2 & 9 & 11 & 20 \\
\hline Total & & 2 classess & 15 & 20 & 35 \\
\hline
\end{tabular}

Because those phenomena employed by the students Insan Utama islamic junior high school pekanbaru some questions are needed to be addressed? What are the students' difficulties in vocabulary? Why do the students get difficulties in language competence and sub competence? Why are the students not able to master vocabulary knowledge? Why are the students not able to master background knowledge? Why student low motivation? Are motivation and vocabulary mastery able to solve students' problem in English subject? Is there any significant diffrence between playing online on vocabulary mastery ? Is there any significant diffrence between playing online game on motivation ? Is there significant effect of playing online vocabulary games on students' vocabulary mastery? Is there motivation on students' vocabulary mastery?

Pullido \& Hambrick (2008) found that knowledge of vocabulary to be an indicator of the quality of a person's vocabulary. In relation to the theoretical ideas, vocabulary is the key factor to ensure that production (receptive vocabulary and productive vocabulary) to get vocabulary as the key factor need a motivation in proces learning. With playing online game it is hoped students have a motivation in learning foreign language especially English subject.

Playing online game can relax for students because young learners like games. Based on Ashraf (2014:290), gamers became more intersted in playing online and wished to achieve better result. Students more interactive and motivating and effective in vocabulary. It is the researchers' reasone to choose online game for up grading students motivation and increase students' vocabulary. Study got significant impact and change for the students learning, motivation and vocabulary. study got significant impact and change for the students learning, motivation and vocabulary (Ashraf,2014:290).

Based on the background and statements of the problem above the researcher imposible to solve all those problem and the researcher focused on investigating the effect of playing online vocabulary games and motivation on students vocabulary mastery in insan utama islamic junior high school pekanbaru academic year 2019/2020. The subject of this research was limited at the seven grade in the School. This research focused on effect playing online game students' motivation and vocabulary mastery. in this research vocabulary mastery given written test.

Vocabulary mastery (Hornby, 200:144) know the word, meaning, formation, and grammar use in particular language and subject. It might online vocabulary games can improve students' word, grammar and meaning in particular language in the school, in their house and everywhere. In another hand online vocabulary games easy, fun, interesting to improve students' vocabulary. It supported by computer/ laptop / gadget / mobile phone and most importantly internet connection. In the case, researcher also limit either vocabulary or topic which are related to the school material. Thus, vocabulary / common word is used in students' daily life, around house, class and school.

The purpose of the research to find out effect of playing online game on students' motivation and vocabulary mastery. Based on Motlagh (2014:290) online game a possible area for teacher to explore further as researcher, effective facilitation a knowledge and skill. Online element in teaching learning are necessary and playing online vocabulary games has benefit for learner in learning English as foreign language such as increase their activity. 


\section{Research Methods}

This chapter discusses about the methods and the procedures of the research that used by researcher to answer the problem of the research in the previous chapter. The procedures consist of the time and place of the research, research design, population and sample, instrument of the data collecting and data analysis they are as follows:

\section{Research Design}

The design of this research is categorized into experiment research or quantitative research. The experimental research divided into two, true experiment and quasi experimental research. In this study the researcher use quasi experiment research. Quasi experiment research is a type of comparison that compares the effect of giving a treatment to an object and looks at the effect of its treatment. This research, there were three variables playing online vocabulary games (X1) motivation (X2), and vocabulary mastery $(\mathrm{Y})$ one dependent variable and two independent variables.

The study attempts to confine it is framework to measure students' vocabulary mastery and analyzed students' motivation in the class. The design of this research factorial design. Factorial design represent a modification of the between group design in which the researcher studies two or more levels and purpose of this design to study the independent and simultaneous effects or more independent treatment variables on an outcome Craswell (2012).

\section{Location and the Time of the Research}

This research will be conducted at Insan Utama islamic Junior high School Pekanbaru located on Jl. Soekarno Hatta. The duration of the research April to May 2020.

\section{Subject and Object of the Research}

Based on the title of the research, the subject of the research was the seven grade students of Insan Utama junior high school Pekanbaru. The object of this research was the effect of playing online game vocabulary games and motivation on students' vocabulary mastery in Insan Utama islamic junior high school Pekanbaru

\section{The Population and Sample of the Research}

All population in Insan Utama Islamic junior high school 106 students. The researcher choose seven grade as subject of the research. The population for sample of seven grade students Insan Utama 35 respondents. Actually in this school, there were consist of 2 classes for seven grade.

The sample of the research consisted of two class comprised of 35 respondents. 15 students control class (VII.1) and 20 experiment class (VII.2). The sample of this study used a purposive sampling. Cohen (120: 2005) stated that the purposive sampling is non probability sample researcher handpick the case to be included in the sample but it is not representative of the population

\section{Technique of Collecting Data}

In order to get the data which were needed to support this study, the researcher used two tests and one questionnaire as the instruments. They were administered to find out the effect of playing games and motivation on students' vocabulary mastery in Insan utama islamic junior high school Pekanbaru and test for vocabulary mastery.

\section{Data Analysis Technicque}

Data Analysis Technicque to analysis the data of informatopn about students' vocabulary mastery and motivation of the students. In this part the researcher needed to test homogenity and 
normality if the data. Homogenity is used a refrence material for determining statistical test decision and normality of the test the researchr had to find out the normality test of the data. The normal distribution analysis use Kolmogorof -Smirnov method.

\section{Result and Discussion}

The analysis of the data were measure from the instrument, test and questioner. More data about this research the researcher present bellow:

\section{Results}

The purpose of this research was to find out the significant difference in vocabulary mastery between those who were taught by playing online vocabulary games and without being taught by online vocabulary games. The data of the research were gotten by test. The test was used to gather the data about students' vocabulary mastery. Another purpose of this research was to find out interaction effect of playing online vocabulary games on students' motivation and vocabulary mastery in Insan utama Islamic Junior High School.

There were two classes taken in this research. The first class was experimental class and the second class was control class. The experimental class was taught online vocabulary games, this group had a new treatment by using this media. There were several of treatments and they might playing this game as additional knowledge. The control class was taught by using conventional to avoid the influence of new intervention.

The researcher used the same question format of pre-test and post-test for experimental class and control class. The result of vocabulary test was evaluated by concerning several components: (a); students ability to know the opposite/ similar and meaning of the words; (b) students can use the good words in grammatically; (c) students ability to know about word formation (noun, adjective, verb and adverb); (d) students ability to spell the spelling of the words correctly.

The purpose of this part to show the significant difference in vocabulary mastery between those who were taught by playing online vocabulary games and without being taught by online vocabulary games. The data of the research were gotten by test. The test was used to gather the data about students' vocabulary mastery and the data of the research were the scores of students' pre-test, post-test from experimental and control group at Insan Utama Islamic junior high school Pekanbaru. The collecting of the data following procedures:

The students VII.1 and VII.2 got pre-test of vocabulary mastery and experiment class got treatment by online vocabulary games and control class without playing online vocabulary games. The next step student of experiment class and students control class got post-test by asking them to answer the question and the students answer sheets of control class and experiment class were collected in order to get the data about their vocabulary mastery and students motivation.

And result of this study on students' taught treatment in experimental class and students without taught treatment, significant differnce of vocabulary mastery between students with low and high motivation after being taught by using online vocabulary games and without online vocabulary game and result of interaction effect of playing online vocabulary games and students' motivation on vocabulary mastery in Insan Utama Islamic Junior High School as follow:

1. Is there any significanct difference of vocabulary mastery between students' taught by using online vocabulary games and without online vocabulary game? (RQ 1) 
Table 4.1

Independent Sample T-Test in Post Test Experiment and Control Class

\begin{tabular}{|lc|c|c|c|c|}
\hline \multicolumn{1}{|c|}{ Subject } & & & & \\
& $\mathrm{N}$ & Mean & Std. Deviation & Std. Error Mean \\
\hline $\begin{array}{l}\text { Post-test experiment } \\
\text { Post-test control }\end{array}$ & 1 & 20 & 83.7500 & 7.04777 & 1.57539 \\
& 2 & 15 & 77.0000 & 7.27029 & 1.87718 \\
\hline
\end{tabular}

Based on the table 4.1, that the number of the students of each group is difference. Experimental class 20 participants and control class 15 participants. The means score of post-test of experimental class was $\mathbf{8 3 . 7 5}$ and mean score of control class 77.00. The standard deviation from the table post-test experimental group 7.04 and pre test control group 7.27. Next information about the table can be seen on standard error mean of post-test experiment 1.64 and post-test control 1.87. More about independent $\mathrm{T}$-Test analysis for post-test vocabulary mastery in experimental group and control group.

Table 4.2

Independent Samples Test

\begin{tabular}{|c|c|c|c|c|c|c|c|c|c|c|}
\hline & \multicolumn{2}{|c|}{$\begin{array}{c}\text { Levene's } \\
\text { Test for } \\
\text { Equality of } \\
\text { Variances } \\
\end{array}$} & \multicolumn{7}{|c|}{ t-test for Equality of Means } \\
\hline & & \multirow[b]{2}{*}{$\mathrm{F}$} & \multirow[b]{2}{*}{ Sig. } & \multirow[b]{2}{*}{$\mathrm{T}$} & \multirow[b]{2}{*}{ df } & \multirow{2}{*}{$\begin{array}{c}\text { Sig. } \\
(2- \\
\text { tailed } \\
)\end{array}$} & \multirow{2}{*}{$\begin{array}{c}\text { Mean } \\
\text { Differen } \\
\text { ce }\end{array}$} & \multirow{2}{*}{$\begin{array}{c}\text { Std. } \\
\text { Error } \\
\text { Differen } \\
\text { ce }\end{array}$} & \multicolumn{2}{|c|}{$\begin{array}{c}95 \% \text { Confidence } \\
\text { Interval of the } \\
\text { Difference }\end{array}$} \\
\hline & & & & & & & & & Lower & Upper \\
\hline $\begin{array}{l}\text { Post } \\
\text { test }\end{array}$ & $\begin{array}{l}\text { Experime } \\
\mathrm{nt} \\
\text { Control }\end{array}$ & .040 & .844 & $\begin{array}{l}2.767 \\
2.754\end{array}$ & 29.7 & .009 & $\begin{array}{l}6.75000 \\
6.75000\end{array}$ & 2.43981 & 1.78618 & $\begin{array}{r}11.713 \\
82 \\
11.75 \\
10\end{array}$ \\
\hline
\end{tabular}

The table 4.2 shows that there is significant difference if the pre test experimental class and control classes. It showed that sig $\mathbf{0 . 0 0 9}$ significant level is smaller than significant value (0.05). The first line equal variances assumed is used. The degree of freedom the data was $\mathbf{3 3}$ and correlate with either $5 \%$ or $1 \%$ significance level. The result showed that the value there is significant difference of vocabulary mastery between students taught by using online vocabulary games and without treatment online vocabulary games. It mean $\mathrm{Ha}$ is accepted and Ho is rejected. 
Table 4.3

Paired Samples Statistics of Experiment class

\begin{tabular}{|lc|c|c|c|c|}
\hline & Mean & N & Std. Deviation & Std. Error Mean \\
\hline Pair 1 & Pre-test Expetriment & 70.5000 & 20 & 8.09483 & 1.81006 \\
& & & & \\
& & & & \\
& Post -test Experiment & 83.7500 & 20 & 7.04777 & 1.57593 \\
& & & & \\
\hline
\end{tabular}

The table demonstrate that the output of paired sample t-test show that t-test result is mean score in pre-test $\mathbf{7 0 . 5 0}$ and after treatment mean score of post-test experimental class is $\mathbf{8 3 . 7 5}$ the standard deviation of pre-test $\mathbf{8 . 0 9 4}$ and post-test experiment class 7.340. in the table show standard error mean for pre-test experiment 1.810 and post- test experimental class 1.641.

Table 4.4

Paired Sample T-Test Statistic In Control Class

\begin{tabular}{|c|c|c|c|c|}
\hline & Mean & $\mathrm{N}$ & Std. Deviation & Std. Error Mean \\
\hline $\begin{array}{cc}\text { Pair } & \text { Pre-test Control } \\
1 & \\
& \\
& \text { Post -test } \\
& \text { Control }\end{array}$ & $\begin{array}{r}73.0000 \\
77.0000\end{array}$ & 15 & $\begin{array}{l}8.61892 \\
7.27029\end{array}$ & 2.22539 \\
\hline
\end{tabular}

The table shows the number of students in control class 15 participants. The mean score of the pre-test control class $\mathbf{7 3 . 0 0}$ and post test score in control class 77.00. Standard deviation of pre-test control 8.618 and post-test of control class 7.270. Information of the table about standard error mean of pre-test control class 2.22 and post-test control class 1.877

Table 4.5

Paired Samples Test In Control Class

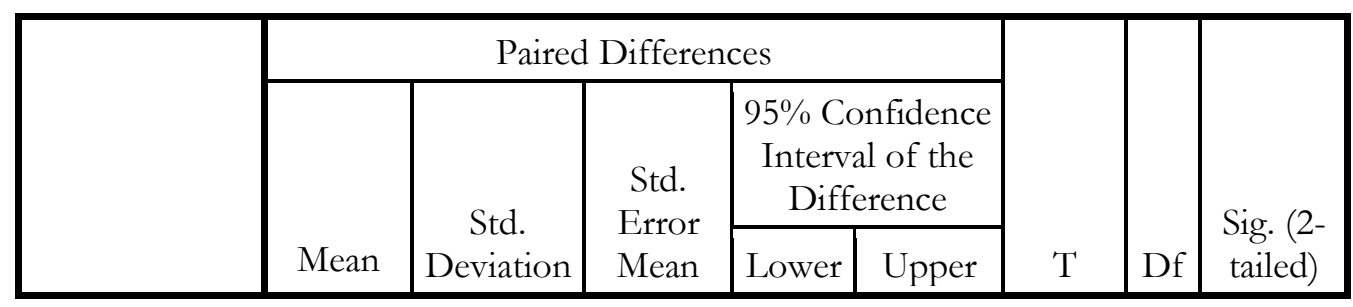

Tanjak: Jounal of Education and Teaching, Vol. 1, No. 2, 2020 
Table 4.5

Paired Samples Test In Control Class

\begin{tabular}{|c|c|c|c|c|c|c|c|c|c|}
\hline & & \multicolumn{5}{|c|}{ Paired Differences } & \multirow[b]{3}{*}{$\mathrm{T}$} & \multirow[b]{3}{*}{ Df } & \multirow{3}{*}{$\begin{array}{l}\text { Sig. (2- } \\
\text { tailed) }\end{array}$} \\
\hline & & \multirow[b]{2}{*}{ Mean } & \multirow{2}{*}{$\begin{array}{c}\text { Std. } \\
\text { Deviation }\end{array}$} & \multirow{2}{*}{$\begin{array}{l}\text { Std. } \\
\text { Error } \\
\text { Mean }\end{array}$} & \multicolumn{2}{|c|}{$\begin{array}{c}95 \% \text { Confidence } \\
\text { Interval of the } \\
\text { Difference } \\
\end{array}$} & & & \\
\hline & & & & & Lower & Upper & & & \\
\hline $\begin{array}{l}\text { Pair } \\
1\end{array}$ & $\begin{array}{l}\text { Pre-test } \\
\text { Control } \\
\text { Post-test } \\
\text { control }\end{array}$ & 4.000 & 6.86607 & 1.77281 & 7.802 & .19770 & 2.256 & 14 & .041 \\
\hline
\end{tabular}

This table demonstrates that the output of paired sample T-test shows that t-test result is 2.256, it compared by getting the freedom ( $\mathrm{df}$ ) 14 , significant of $\mathbf{0 . 4 1}$. The mean differences is 4 . The standard deviation 6.866 and standard error mean is 1.772. the lower difference interval is $\mathbf{7 . 8 0 2}$ and upper interval 1.977

Based on the table 4.4 and table 4.5 showed mean score of experiment class before treatment $\mathbf{7 0 . 5 0}$ and after treatment mean score of experiment class $\mathbf{8 3 . 7 5}$ for control class in pre-test mean score of them 73 and post test of control class $\mathbf{7 7}$. The conclusion of table 4.4 and 4.5 there is significant difference between vocabulary mastery post test mean score of the esxperiment class in Insan Utama Islamic Junior High School Pekanbaru.

For more detail about the data the researcher put the table of post-test experimental class and control class in table 4.7. The table show 35 participants there are 20 experiment class and 15 control class. The calculation of the total post test score of experimental class is 1675 , the mean of the post test score of experimental class is $\mathbf{8 3 . 7 5}$ and post test of control group is $\mathbf{7 7}$. The result of this research is there is significant difference of vocabulary mastery between students taught by online vocabulary games. It can be seen in means score of the test $\mathbf{7 0 . 5 0}$ before the treatment and after treatment in experiment class the mean score class was $\mathbf{8 3 . 7 5}$.

The result of this part $\mathrm{Ha}$ is accepted and Ho is rejected it can be seen significant score of experiment class in pre- test $\mathbf{7 0 . 5 0}$ and after treatment was $\mathbf{8 3 . 7 5}$ the conclusion is there is significant difference of vocabulary mastery between students taught by online vocabulary games and without treatment games in class control. The data of post test experiment and control class showed in table 4.6 the table in below:

Table 4.6

Post-test Score after treatment in experimental class and Without treatment in control class

\begin{tabular}{|c|c|c|c|}
\hline No. & STUDENTS & $\begin{array}{c}\text { Score experiment after } \\
\text { treatment }\end{array}$ & Score control class \\
\hline 1 & Student 1 & 80 & 75 \\
\hline 2 & Student 2 & 85 & 70 \\
\hline
\end{tabular}




\begin{tabular}{|c|c|c|c|}
\hline 3 & Student 3 & 80 & 85 \\
\hline 4 & Student 4 & 90 & 60 \\
\hline 5 & Student 5 & 95 & 70 \\
\hline 6 & Student 6 & 75 & 80 \\
\hline 7 & Student 7 & 80 & 90 \\
\hline 8 & Student 8 & 85 & 75 \\
\hline 9 & Student 9 & 80 & 80 \\
\hline 10 & Student 10 & 80 & 75 \\
\hline 11 & Student 11 & 95 & 80 \\
\hline 12 & Student 12 & 85 & 75 \\
\hline 13 & Student 13 & 95 & 80 \\
\hline 14 & Student 14 & 90 & 75 \\
\hline 15 & Student 15 & 90 & 85 \\
\hline 16 & Student 16 & 80 & - \\
\hline 17 & Student 17 & 75 & - \\
\hline 18 & Student 18 & 80 & - \\
\hline 19 & Student 19 & 70 & - \\
\hline 20 & Student 20 & 85 & -095 \\
\hline & Total & 1675 & 83.575 \\
\hline & Mean score & 83.75 & - \\
\hline
\end{tabular}

Mean score of post- test of experiment class and control calss was $\mathbf{8 3 . 5 7}$ in experiment class and 77 in contro 1 class. About this score answer the question of the hypothesis below: The procedure of inferential statistics began with the statistical test on the following null hypothesis:

Ho1: There is no significant difference between vocabulary mastery post- test mean score of the experimental class and control class on vocabulary mastery Insan Utama Islamic Junior High School Pekanbaru.

Ha1: There is a significant difference between vocabulary mastery post- test mean score of the experimental class and control class on vocabulary mastery Insan Utama Islamic Junior High School Pekanbaru.

The conclusion is $\mathrm{Ha}$ is accepted and Ho us rejected. Because there is a significant difference between vocabulary mastery post- test mean score of the experimental class and control class on vocabulary mastery Insan Utama Islamic Junior High School Pekanbaru. The table $\mathbf{4 . 2}$ shows that there is significant difference if the pre test experimental class and control classes. It showed that sig $\mathbf{0 . 0 0 9}$ significant level is smaller than significant value $(0.05)$. 
2. Is there any significant differnce of vocabulary mastery between students with low and high motivation after being taught by using online vocabulary games and without online vocabulary game? (RQ 2)

The procedure of inferential statistics began with the statistical test on the following null hypothesis for research question 2:

Ho2: There is no significant difference of vocabulary mastery between students who have high and low motivation in experimental class and control class at Insan Utama Islamic Junior High School Pekanbaru.

Ha2: There is a significant difference of vocabulary mastery between students who have high low motivation in experimental class and control class at Insan Utama Islamic Junior High School Pekanbaru

Table 4.7

Independent Samples Test

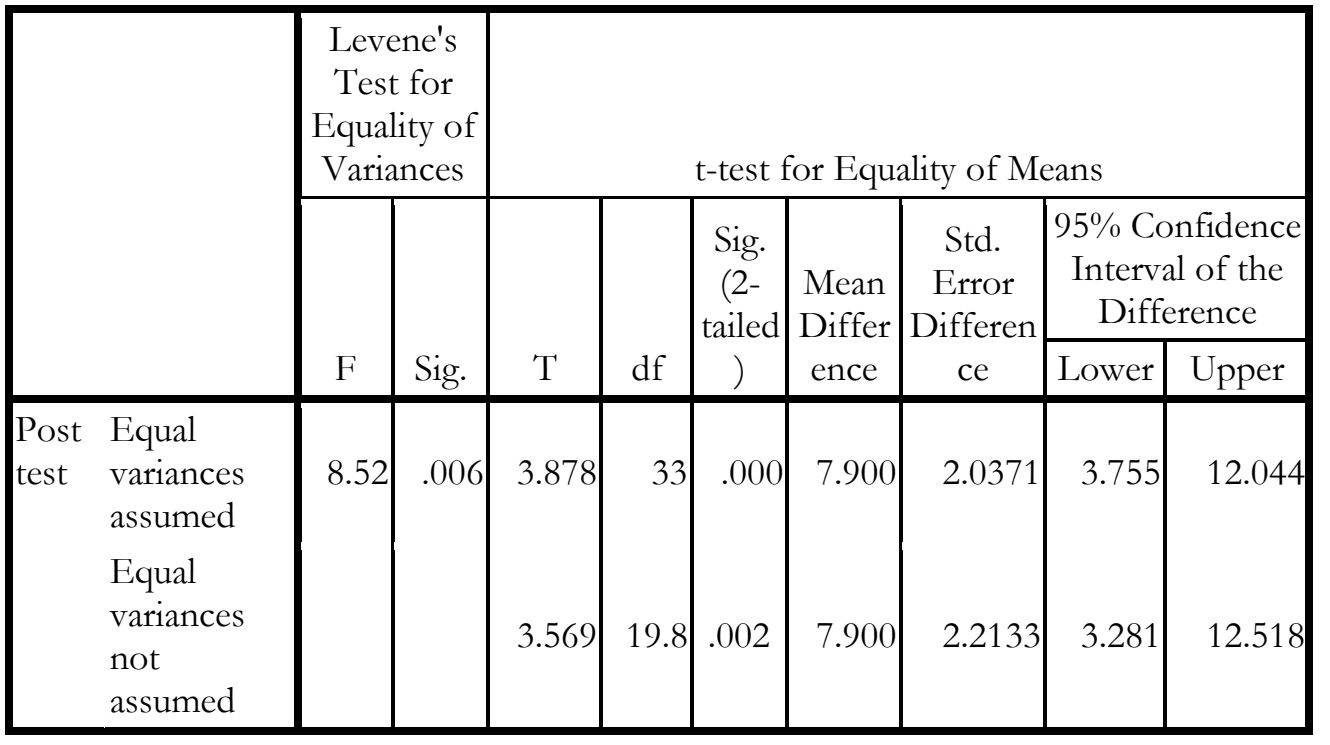

Based on the table 4.7 above showed information about independent sample T-test for post-test vocabulary mastery between high motivation and low motivation. Levene's Test show Sig (2-tailed) $\mathbf{0 . 0 0}$ smaller than $\mathbf{0 . 0 5}$ The result of this study indicate there is significant difference in students motivation post test experiment between control class high motivation and low motivation. More detail about statistic the researcher put the table bellow:

Table 4.8

Group Statistics post test Experiment and Control

\begin{tabular}{|ll|c|c|c|c|}
\hline \multicolumn{1}{|c|}{ Class } & $\mathrm{N}$ & Mean & Std. Deviation & $\begin{array}{c}\text { Std. Error } \\
\text { Mean }\end{array}$ \\
\hline Post test & experiment & 20 & 56.3000 & 4.13076 & .92367 \\
& Control & 15 & 48.4000 & 7.79010 & 2.01140 \\
\hline
\end{tabular}


Based on the table of $\mathbf{4 . 8}$ post test score of experiment class $\mathbf{5 6 . 3 0}$ and mean score of control class 48.40. standar deviation of experiment class 4.13076 and control class $\mathbf{7 . 7 9 0 1 0}$ about standar error mean of experiment class 92367 and 2.01140. The table showed class experiment got higher score in mean score than cintril group. More detail about the data of post test score between experiment class and control class as below:

\subsection{The Data of Post Test}

Students High Motivation and Low Motivation in Experiment class

\begin{tabular}{|c|c|c|c|}
\hline No & student & Post test Experiment class & Level Motivation \\
\hline 1 & Student 1 & 58 & High \\
\hline 2 & Student 2 & 55 & High \\
\hline 3 & Student 3 & 56 & High \\
\hline 4 & Student 4 & 49 & Low \\
\hline 5 & Student 5 & 65 & High \\
\hline 6 & Student 6 & 59 & High \\
\hline 7 & Student 7 & 53 & High \\
\hline 8 & Student 8 & 55 & High \\
\hline 9 & Student 9 & 49 & Low \\
\hline 10 & Student 10 & 54 & High \\
\hline 11 & Student 11 & 54 & High \\
\hline 12 & Student 12 & 55 & High \\
\hline 13 & Student 13 & 60 & High \\
\hline 14 & Student 14 & 52 & High \\
\hline 15 & Student 15 & 60 & High \\
\hline 16 & Student 16 & 53 & High \\
\hline 17 & Student 17 & 60 & High \\
\hline 18 & Student 18 & 60 & High \\
\hline 19 & Student 19 & 59 & High \\
\hline 20 & Student 20 & 60 & High \\
\hline & Total & 1126 & \\
\hline & Mean & 56,3 & \\
\hline
\end{tabular}

Table 4.10

The Data Presentation of Students

High and Low Motivation in control class

\begin{tabular}{l|l|c|c|}
\hline No & Students & Control class & Level Motivation \\
\hline 1 & Student 1 & 47 & Low \\
\hline 2 & Student2 & 48 & Low \\
\hline 3 & Student3 & 36 & Low \\
\hline
\end{tabular}




\begin{tabular}{l|l|c|c}
4 & Student4 & 44 & Low \\
\hline 5 & Student5 & 58 & High \\
\hline 6 & Student6 & 41 & Low \\
\hline 7 & Student7 & 43 & Low \\
\hline 8 & Student8 & 45 & Low \\
\hline 9 & Student9 & 58 & High \\
\hline 10 & Student10 & 51 & High \\
\hline 11 & Student11 & 53 & High \\
\hline 12 & Student12 & 59 & High \\
\hline 13 & Student13 & 38 & Low \\
\hline 14 & Student14 & 45 & Low \\
\hline 15 & Student15 & 60 & High \\
\hline & Total & 726 & \\
\hline & & 48.40 & \\
\hline
\end{tabular}

Table 4. 11

Group Statistics mean Score

of High and Low Motivation in control class

\begin{tabular}{|r|c|c|c|c|}
\hline Post test & $\mathrm{N}$ & Mean & $\begin{array}{c}\text { Std. } \\
\text { Deviation }\end{array}$ & $\begin{array}{c}\text { Std. Error } \\
\text { Mean }\end{array}$ \\
\hline Control class & 15 & 48.40 & 7.790 & 2.011 \\
\hline
\end{tabular}

Result on table 4.8 mean score of post-test experiment class higher than post- test control class. Table 4.11 showed means score of post test mean score of post-test in control class 48.40. The conclusion is there is significant difference of vocabulary mastery between students with low and high motivation after being taught by playing online games and without treatment the game. class control 7.790 for standard error mean 2.011. the researcher found the result of means score in post test control group still low.

The result found there is a significant difference of vocabulary mastery between students who have high low motivation in experimental class and control class at Insan Utama Islamic Junior High School Pekanbaru. Ha is accepted and Ho is rejected. It can be seen in the table 4.7 and showed sig 2 tailed $\mathbf{0 . 0 0}$ smaller than $0.05 \%$

3. Is there any interaction effect of playing online vocabulary games and students' motivation on vocabulary mastery in Insan Utama Islamic Junior High School? (RQ 3)

The procedure of inferential statistics began with the statistical test on the following null hypothesis:

Ho3: There is no significant interaction effect between online vocabulary games and motivation on students' vocabulary mastery at Insan Utama Islamic Junior High School Pekanbaru. 
Ha3: There is a significant interaction effect between online vocabulary games and motivation on students' vocabulary mastery at Insan Utama Islamic Junior High School Pekanbaru.

Table 4.12

\section{Tests of Between-Subjects Effects}

Dependent Variable:

Experiment and Control

\begin{tabular}{|c|c|c|c|c|c|}
\hline Source & $\begin{array}{c}\text { Type III Sum } \\
\text { of Squares }\end{array}$ & Df & Mean Square & F & Sig. \\
\hline Corrected Model & $396.508^{\mathrm{a}}$ & 3 & 132.169 & 2.442 & .083 \\
Intercept & 125022.593 & 1 & 125022.593 & $2.310 \mathrm{E} 3$ & .000 \\
Motivation & .370 & 1 & .370 & .007 & .935 \\
class & 250.370 & 1 & 250.370 & 4.626 & .039 \\
Motivation * class & 5.926 & 1 & 5.926 & .109 & .743 \\
Error & 1677.778 & 31 & 54.122 & & \\
Total & 230900.000 & 35 & & & \\
Corrected Total & 2074.286 & 34 & & & \\
\hline
\end{tabular}

a. $\mathrm{R}$ Squared $=, 191$ (Adjusted R Squared $=, 113$ )

From the analysis result in table 4.12 , it was found that there was no interaction effect between playing online vocabulary games and motivation on students' vocabulary mastery. It was performed by using Two Ways Anova Test. It can be seen table 4.12 it is mean bigger than significant level 5\%. The conclusion is Ho accepted is and $\mathrm{Ha}$ is rejected

The advantages of using Two Way ANOVA design the test "main effect" for each Independent variable and also explore the posibility of an interaction effect . if the significant value greater than $>0.05$ there is no significant. If the significance value is smaller than $<0.05$ it mean there is significance. So, it can be conclude by playing online vocabulary games and motivation on students' vocabulary mastery referring two way ANOVA test there is no interaction with significant.

Table 4.13

The data of students' Motivation in Class Control

\begin{tabular}{|c|l|c|c|}
\hline No & student & Post test Experiment class & Level Motivation \\
\hline 1 & Student 1 & 58 & High \\
\hline 2 & Student 2 & 55 & High \\
\hline 3 & Student 3 & 56 & High \\
\hline 4 & Student 4 & 49 & Low \\
\hline 5 & Student 5 & 65 & High \\
\hline 6 & Student 6 & 59 & High \\
\hline 7 & Student 7 & 53 & High \\
\hline 8 & Student 8 & 55 & High \\
\hline 9 & Student 9 & 49 & Low \\
\hline 10 & Student 10 & 54 & High \\
\hline
\end{tabular}

Tanjak: Jounal of Education and Teaching, Vol. 1, No. 2, 2020 


\begin{tabular}{|c|c|c|c|}
\hline 11 & Student 11 & 54 & High \\
\hline 12 & Student 12 & 55 & High \\
\hline 13 & Student 13 & 60 & High \\
\hline 14 & Student 14 & 52 & High \\
\hline 15 & Student 15 & 60 & High \\
\hline 16 & Student 16 & 53 & High \\
\hline 17 & Student 17 & 60 & High \\
\hline 18 & Student 18 & 60 & High \\
\hline 19 & Student 19 & 59 & High \\
\hline \multirow[t]{3}{*}{20} & Student 20 & 60 & High \\
\hline & Total & 1126 & \\
\hline & Mean & 56,3 & \\
\hline
\end{tabular}

Table 4.13 about mean score in post-test control class, about post -test control class mean score got $\mathbf{7 7 . 0 8 3}$ standard deviation $\mathbf{1 . 9 3 9}$ lower biund $\mathbf{7 3 . 1 2 9}$ and upper Bound $\mathbf{8 1 . 0 7 3}$

Table 4.14

Mean Score in Post-test Control Class

Dependent Variable:experimentandcontrol

\begin{tabular}{|c|c|c|c|c|}
\hline \multirow[b]{2}{*}{ Class } & \multirow[b]{2}{*}{ Mean } & \multirow[b]{2}{*}{ Std. Error } & \multicolumn{2}{|c|}{$95 \%$ Confidence Interval } \\
\hline & & & Lower Bound & Upper Bound \\
\hline control & 77.083 & 1.939 & 73.129 & 81.037 \\
\hline
\end{tabular}

To answer the hypothesis it can be seen on table and interaction between variable of research question was no significant interaction effect between online vocabulary games and motivation on students' vocabulary mastery at Insan Utama Islamic Junior High School Pekanbaru. It mean Ho accepted and Ha was rejected.

\section{Discussion}

The data was collected, analyzed and found the result.After doing the research and treatment the researcher got experiences how deep online learning or internet zone. Internet and online help peoples' work at home, school and everywhere. The researcher interested to know motivation of students and using online vocabulary game on students' vocabulary mastery and apply in teaching and learning to measure the interaction effect playing online vocabulary games and motivation on students' vocabulary mastery.

\section{The effectiveness of online vocabulary games on students' vocabulary mastery}

To investigate the first question, an independent sample $\mathrm{T}$-test was conducted. The T- test was intended to compare the obtained mean score of the participants in the control and experimental class in post-test to indicate the effectiveness of the treatment. The game as an effective way to help students enjoy and entertain with the language they learn. 
Based on the research question and hypothesis "is there significant difference in vocabulary mastery between taught by using online vocabulary games and taught without online vocabulary games? this question answering by the data post-test experimental class and control class on table 4.8 T-test result was $\mathbf{0 . 6 8 8}$ and df 33, standard deviation of experimental class 8.61 and control class $\mathbf{8 . 0 9}$ the conclusion is the sig. 2 tailed $\mathbf{0 . 0 0 9}$ it bigger than $0.05 \%$. and another difference of experimental class and control class. Mean score of pre-test and post-test in experiment class was $\mathbf{7 0 . 5 0}$ and $\mathbf{8 3 . 7 5}$ and post-test control class was $\mathbf{7 7 . 0 0}$

In this part the researcher used collaborative with the teacher and result showed that the subjects in both of groups got different mean scores. It provides students with opportunity treatment to learn and practice new knowledge and examine their thinking process to improve their creativity in process learning the discussion about the effectiveness of vocabulary games on students' vocabulary mastery it allows the finding research before evaluate students' progress, and provides teacher cognitive and affective supports for students understanding.

Based on kwan (2014) the students in experiment group generally prepared online learning with digital educational games and more active and creative based on lesson. It might result and discussion of this research finding appropriate or compatible with the theory and kalyaati (2018) online games effective and motivating.

Conclusion for research question and hypothesis is there is significance difference in vocabulary mastery between taught by using online vocabulary games and taught without online vocabulary games. the literature review on the effect of playing online vocabulary games on students' vocabulary mastery, it can be online vocabulary games are an effective in Insan Utama Islamic Junior High School Pekanbaru.

\section{The influence of motivation on students' vocabulary mastery}

Based on the research question 2" is there any significant difference of vocabulary mastery between students with low and high motivation after being taught by using online vocabulary games and without online vocabulary game". It was found on the table 4.7 and conclude that there is significance difference of vocabulary mastery between students with low and high motivation after being taught by using online vocabulary games and without online vocabulary game it means $\mathrm{Ha}$ is accepted.

Playing online vocabulary mastery and motivation can make students have desire to participate in the classroom or everywhere they play the game. Digital game one of the factor make learners interested and motivated in learning process they can learn vocabulary became fun, easy, enjoy and rised high motivation and low motivation learning English in vocabulary.

Sadeghi (2013) confirmed that students who have high motivational level related significantly to their achievement and most participated in subject or object, about the researcher in his research showed there is influence of motivation on students' vocabulary mastery. The result and discussion of this part showed in the table 4.7 and conclusion was students in experiment class have high motivation is there is significant difference of vocabulary mastery between students with high motivation and low motivation after being treatment playing online vocabulary games.

It support by Sahriarpour (2014) using digital games in education result better motivation and facilities, they have high interested and low stress more active and creative, fun and enjoyable. Banyte 
(2015) games prompted intrinsic motivation and play developed their skills. The researcher conclude there is influence of motivation on students' vocabulary mastery.

The interaction of playing online vocabulary games and motivation on vocabulary mastery

Last discussion about research question 3 "Is there any interaction effect of playing online vocabulary games on students' motivation and vocabulary mastery in Insan Utama Islamic junior high school Pekanbaru based on the research question and finding the data in this research, there is no interaction of playing online vocabulary game and motivation on vocabulary mastery, the researcher found there is no interaction of playing online vocabulary games and motivation on vocabulary mastery it can be seen on the table 4.13 and conclude it was not appropriate with theory

The theory support by the researcher Swando (2014) it leads to the implication that should be more innovative in finding and developing more various media that can be used in their teaching and encourage students' motivation which final result the improvment of their vocabulary mastery. In conclusion, playing online vocabulary games is suitable media to improve students' vocabulary and portable. Portable mean students can playing and improve thier self everywhere and connected with internet.

Wright (2011) findings vidio games or playing online vocabulary games have an ever creating, increasing, entertaiment than ever before. Overall, that can be learned about it. In conclusion, playing online vocabulary games good in the context of school have connectivity with internet and hot spot area. This game can be used as a reference for the teacher to improve the students' low motivation and like playing online gmae to increas their knowladge about the words, because playing online vocabulary games is easily.

Another theory about no interaction effect of this research is jalali (2012) the result no significant effect and no significant difference between experiment class and control class it was conducted Independent sample T-test of his research. However, researcher also finding in SPSS there is no interaction effect of playing oline vocabulary games and motivation on students' vocabulary mastery in Insan Utama Islamic Junior High School Pekanbaru. Even though the research question 3 is not significant, the learners enjoy the games and increase their motivation.

\section{Congclusion}

This research was conducted on April to May and object of this research was students of Islamic Junior High School Pekanbaru. The researcher took two classes as a sampling research. One of the classes was experiment class and other control class. The purpose of this research was carrying out a research on the topic above. Based on several consideration: This research is relevant to her status as an English student of Post Graduate of State Islamic University Sultan Syarif Kasim Riau, the researcher wants to know the students' vocabulary mastery by online vocabulary games at Insan Utama Islamic Junior High School Pekanbaru, The title is interesting because it is related to the problem faced by students and now.

The problem of this research were: Students Insan Utama Islamic junior high school got some problems in vocabulary. First, students hard to understand the meaning of the text/word, sometimes students skip the word / text when students found unknown meaning, lack of vocabulary and background knowledge of vocabulary 
Secondly, the students also had difficulties to use appropriate choice of the words, cannot use grammatically, did not know about word information (noun, adverb, adjective, and verb) some of students confused, part of speech, synonym, antonym, confused word meaning and finding out the unfamiliar words when they are reading and some of students not interesting in English Subject. Based on the background problems also come from students self.

And the third is motivation, it is related to the students' interest in learning. Students who are highly motivated to learn something are more likely to be active than others to consciously plan their learning. It is not easy to mastering vocabulary, based on the table below students might lack of vocabulary / unknown meaning of the word.

To solve the problems, the writer used the online vocabulary games it might help the students to promote creativity in the classroom, house and everywhere to supports the students in vocabulary. Based on the data analysis, about the Effect of playing online vocabulary games and motivation on Students' vocabulary mastery in Insan Utama Islamic Junior High School Pekanbaru comes to the conclusion as follows:

The students who are taught by online vocabulary mastery have than without treatment. Students playing online vocabulary games can be seen from mean score of the experiment research in control and experiment classes. The mean score of students' treatment by playing online vocabulary games is 83,75 than without treatment or control class 77 .

There was a significant difference in vocabulary mastery between the students who had high and low motivation. Therefore, motivation determined the success of students' ability in vocabulary mastery. There is positive influence who had high motivation and playing online vocabulary games on vocabulary mastery was interesting and could motivate students to learning English easily, happy and creative and was an interaction effect between online vocabulary games and motivation on students' vocabulary mastery.

The result of data analysis by using Independent t-test for research question 1 and 2 . The last research question answer by Two-Way ANOVA. The formula is higher than the $t_{\text {table }}$ it means that null hypothesis $\left(\mathrm{H}_{\mathrm{o}}\right)$ is rejected, while the alternative hypothesis $\left(\mathrm{H}_{\mathrm{a}}\right)$ is accepted. It means positive interaction effect between playing online vocabulary mastery and motivation on students' vocabulary mastery. It can be concluded that the students' vocabulary mastery is influence by playing online vocabulary games being used and motivation.

For research question 1 and 2 there is significant difference of vocabulary mastery between students taught by using online vocabulary games and without treatment the games it can be seen in mean score of experimental class and control class. Next result the researcher found difference of vocabulary mastery between students with high motivation and low motivation after being playing online vocabulary games it can be seen score of post-test in experimental class and control class. The conclusion between research question 1 and 2 is Ha accepted and Ho rejected.

In another case, for research question 3 is $\mathrm{Ho}$ is accepted and $\mathrm{Ha}$ is rejected. The table of interaction effect of playing online vocabulary games and students motivation on vocabulary mastery can be seen on the table sig. 2 tailed is higher than 0,05 . Conclusion of this research there is no significant difference between students taught online vocabulary games between experiment class and control class and have high and low motivation after being treatment online vocabulary games and without the treatment. 


\section{Referensi}

Adams, Ernest. (2010). Fundamentals of Game Design. Second Edition. California:Perason Education,Inc. Alderson, J.C. (2000). Assessing reading. Cambridge: Cambridge University Press.

Alfaki, I. M., \& Siddiek, A.G. (2013). The Role of Background Knowledge in Enhancing Reading Comprehension. World Journal of English Language. Vol. 3, No. 4.

Alizadeh, Mitra. (2016). The Impact of Motivation on English Language Learning. International Journal of Research in English Education. Vol. 1, No.1

Alshawi, Wadeeah. (2016). Using Vidio Games To Increase Motivation of Saudo Students Learning English. P.Hd disertation: Wayne State Univeristy

Anisa (2016). Analysis Pengaruh Game Online Terhadap Language Comprehansion Dalam Kemampuan Berbahasa Inggris. Binus University.

Anjomshoa, L., \& Zamanian, M. (2014). The Effect of Vocabulary Knowledge on Reading Comprehension of Iranian EFL Learners in Kerman Azad University. International Journal on Studies in English Language and Literature (IJSELL). Volume 2, Issue 5, PP 90-95

Anderson, R. C., \& Freedy, P. (1981). Vocabulary Knowledge. In Guthrie, J. T. (Eds.), Comprehension and teaching: Research reviews (pp. 77-117). Newark, DE: International Reading Association.

Anderson, R. C., \& Pearson, P. D. (1984). A schema-theoretic view of basic processes in reading comprehension. In P. D. Pearson (Ed.), Handbook of reading research (pp.255-292). New York, NY: Longman.

Ashraf,H \& Maryam Salami. (2016) The Impact Of Game on Learning English Vocabulary by Iranian (Low Intermediate) EFL Learners. Elsevier : Urnia University of Iran.

Baek, Youngkyun. (2010). Gaming for classroom-based learning: digital role playing as a motivator of study. The United States of America: Information Science Reference (an imprint of IGI Global).

Banyte, J.\& Agne Gadeikiene (2015). The Effect of Consumer Motivation to Play Games Online on Vodio Game-Playing Engagement. Lithuania: Kaunas University of technology.

Baumann, J. F. (2005). Vocabulary-comprehension relationships. In B. Maloch, J. V. Hoffman, D. L. Schallert, C. M. Fairbanks, \& J. Worthy (Eds.), Fifty-fourth yearbook of the National Reading Conference (pp. 117-131). Oak Creek, WI: National Reading Conference.

Biemans, H.J.A. \& Simons, P.R., (1996). CONTACT-2: A computer-assisted instructional strategy for promoting conceptual change. Instructional Science, 24, 157-176.

Brantmeier, C. (2004). Gender, violent-oriented passage content and second language reading comprehension. The Reading Matrix, 4(2), 1-19.

Brink, H.I.L.(1993). Validity and Reliability in Quantitative Research. Curationis, Vol 16, No. 2.South Africa Brown, S. (2006). Teaching listening. Cambridge: Cambridge University Press.

Brown, Jennefer. (2014). Teacherse perceptions and uses of online gaming and virtual worlds for English language learning. Dissertation. London: University of Exeter.

Cameron, Lynne. (2001). Teaching Language to Young Learner . Cambridge Language Teaching lobrary: Cambridge : Cambridge University perss.

Chastain, k. (1988). Developing second language skills: Theory and practice (3rd ed.). San Diego: Harcourt Brace Jovanovich 
Chou, P.T.M. (2011). The Effects of Vocabulary Knowledge and Background Knowledge on Reading Comprehension of Taiwanese EFL Students. Electronic Journal of Foreign Language Teaching, Vol. 8, No. 1, 108 115.

Cohen, L., Manion, L. and Morrison, K. R. B. (2007). Research Methods in Education (sixth edition). London: Routledge

Crawford, Chris. (1984). The Art of Computer Game Design. Electronical Edition. University Vancouver

Cresswell, Jhon., W. (2008). Education Research: Planning Conducting, and Evaluating Quantitative and Qualitative Research. New Jersey: Pearson Education.

Cresswell, Jhon, w. (2012). Education Research: Planning Conducting, and Evaluating Quantitative and Qualitative Research. Boston: Pearson Education

Damayanti, R. (2019). Instrumental and Integrative Motivation of Senior High School. Thesis : Unnes.

Daller, H., Milton, J. \& Treffers-Daller, J. (Eds.). (2007). Modelling and Assessing Vocabulary Knowledge. Cambridge, UK: Cambridge University Press.

Dausti, Masoumeh \& Jalali Sara (2012). Vocabulary and Grammar Gain Through Computer Educational Games. Gema Online Journal of Language Studies. Vol 12. 42012.

Depdiknas. 2006. Kurikulum Tingkat Satuan Pendidikan. Jakarta

Depdiknas. 2006. Standar Kompetensi dan Kompetensi Dasar tingkat SMP/MTS. Pekanbaru. Dispora

Dorney, Z. (2009). Motivation In Second And Foreign Language Learning. Cambridge, UK: Cambridge University Press.

Elda, Martha, S. (2012). Improving students' vocabulary mastery by using song at Grade sixpf Elementry School Bungo Pasang Padang. Vol. 1, No1.pp.115-135

Eskasasnanda, Dewa P. (2017). Causes and Effects of Online Vidio Game Playing among Junior-High School Students in Malang East Java. International Journal Indonesia Society and Culture. Vol 9 (2) .pp 191-202

Farvardin, M.T. \& Koosha, M. (2011). The Role of Vocabulary Knowledge in Iranian EFL Students' Reading Comprehension Performance: Breadth or Depth? Theory and Practice in Language Studies, Vol. 1, No. 11, pp. $1575-1580$

Gay, L.R and Peter Airasian. (2000). Educational Research Competencies for Analysis and Application. Six Ed.

New Jersey: Prentice-Hall, Inc.

Gadaikiene, Agne \& Banyte, Jurate. (2015). The Effect of Consumer Motivation to Play Games on Vidio GameOlaying Engagment. Elsevier Publishing

Garrdner, R.C \& Lambert, W.E (1972). Attitudes and Motivation in Second Language Learning. Newbury House: Reley M.A

Gardner,R.C. (1994). On Motivation: Measurements and Conceptual Consideration . Modern Language Journal. 78, 359-68

Gardner,R.C. (2001).integrative motivation and language acquisition and motivation . Accesed on January 23-012020.

Gerry, S. http://gameonlinehistory.blogspot.co.id/. Diakses pada: 9 Juli 2016.

Glavack, Renata \& Sporcic, B. (2018). The Relationship Between Online Gaming Motivation, Self Concept Clarity and Tendency Toward Problematic Gaming. Masarark University: journal of Pgysicosocial on Cyberspace.

Halimah, D. N. (2017). Improving Students' Vocabulary Mastery. Thesis: Uin Surakarta. 
Hammadou, J. (1991). Interrelationships among prior knowledge, inference, and language proficiency in foreign language reading. The Modern Language Journal, 75, 27-38.

Harmer, Jeremy. 2001. How to teach English. Edinburg: Longman

Hatch, E. \& Farhady, H. (1982). Research Design ND Statistic for Applied Linguistics. London: Newbury House Publisher.

Hiebert, E.H \& Kamil. (2005). Teaching Learning Vocabulary. Bringing Research to Practice. London: Laurance Elbauom Associates, Inc.

http:/ / namagameonline.blogspot.co.id/)

(http://gameonlinehistory.blogspot.co.id/)

Hu, M. \& Nation, P. (2000). Vocabulary density and reading comprehension. Reading in a Foreign Language, 23, 403-430.

Huang, Qian. (2009). Background Knowledge and Reading Teaching. Asian Social Science.Vol 5. No.5

Hudson, Thom. (2007). Teaching Second Language Reading. Oxford: Oxford University Press.

Hughey, Jane B. et al. 1983.Teaching ESL Composition: Principles and Techniques.London: Newbury House Publishers

Ikhwan, M. N. (2017). The Influence of Students'Mastery of Writer's Text Organization and Vocabulary toward their Reading Comprehension at Islamic Senior High School Al Islam Rumbio. Pekanbaru: State Islamic University Sultan Syarif Kasim Riau.

Jack C. Richards \& Willy A. Renandya. (2002). Methodology in Language Teaching: An Anthology of Current Practice. New York: Cambridge University Press.

Jacobs, Holly L. et al., (1981). Testing ESL Composition: A Practical Approach Tokyo: Newbury House Publishers

Jahwari, Y.A., \& Humaidi, S. A. (2014). Prior Knowledge in EFL Reading Comprehension: Omani Teachers' Perspectives \& Classroom Strategies. International Journal of Applied Linguistics \& English Literature, Vol. 4 No. 1.

Jalilehvand, Maryam. (2014). Impact of Prior Knowledge, Rhetoricalpatterns, and Gender Differences on Reading Comprehension of Iranian EFL Students. $\mathrm{PhD}$ thesis, University of Malaya.

Johnson, P. (1982). Effects of reading comprehension on building background knowledge. TESOL Quarterly, 16, 503-516

Johnston, P. (1999). Prior Knowledge and Reading Comprehension Test Bias. Reading Research Quarterly,19

Joshi, R.M., \& Aaron, P.G. (2000). The component model of reading: Simple view of reading made a little more complex. Reading Psychology, 21, 85-97.

Kafi, Zahra \& Sahriarpour, Nahid. (2014). On the Effect of Playing Digital Games on Iranian Intermediate EFL Learners' Motivation Toward Learning English Vocabularies. Elsavier Publisihing.

Kayaalti, Mahmut. (2018). A Literature Review on the Impact of Online Games in Learning Vocabulary. International Journal of Scientific Research Publication Vol.8

Ke, Fengfeng. (2009). A Qualitative Meta-Analysis of Computer Games as Learning Tools. University of new Mexico: IGI Global.

King, Carol and Nancy Stanley. (2008). Building Skills for TOEFL 2and 5 d. Longman. London

Knuth, R.A \& Jones B. F. (2006). What does Research Say about Reading? In Amber D. Warsnak. The Effects of Activating Prior Knowledge Before Reading on Students with and without Learning Disabilities. 
Koda, K. (1989). The effects of transferred vocabulary knowledge on the development of L2 reading proficiency. Foreign Language Annals, 22, 529-540.

Koh, M. Y. (1984). Prior Knowledge in the Interpretation of Texts. Unpublished PhD thesis, University of London.

Kwan, M. \& Florence W.M (2006). Online Vocabulary Games as Tool for Teaching and Learning English Vocabulary. Educational Media International: International Council. Vol 43.3 pp.233-249.

Laufer, B. \& P. Nation. (1999). A vocabulary size test of controlled productive ability. Language Testing 16, 33-51.

Lee, J. F. (1986). Background knowledge and L2 reading. The Modern Language Journal, 70, 350-354.

Lestari, L.I. (2015) The Effect of Audio Vidio Games Media On Students' Motivation in Listening Comprehansion Thesis :Unnesa.

Longman. (1987). Dictionary Contemporary English. The up to Date Learning Dictionary: Cornll University Press, New York.

L. R. Gay and Peter Airasian. 2000. Educational Research Competencies for Analysis and Application. Six Edition. New Jersey: Prentice- Hall

Manyak, P.C., \& Bauer, E.B. (2009). English Vocabulary Instruction for English Learners. The Reading Teacher, 63(2), 174-176.

Martin-Chang, S.Y., \& Gould, O.N. (2008). Revisiting Print Exposure: Exploring Differential Links to Vocabulary, Comprehension and Reading Rate. Journal of Research in Reading, 31, 273-284.

Mehrpour, S., Razmjoo, S., \& Kian, P. (2011). The Relationship between Depth and Breadth of Vocabulary Knowledge and Reading Comprehension among Iranian EFL Learners. Journal of English Language Teaching and Learning, No. 222, 97-127.

Milton J.(2009). Measuring Second Language Vocabulary Acquisition. Cambridge: Multilingual Matters.

Moats L. (2005). How Spelling Supports Reading And Why It Is More Regular and Predictable Than You May Think. American Educator Winter 2005/2006, 12-43.

Moghadam, et. al. (2012). A Review on the Important Role of Vocabulary Knowledge in Reading Comprehension Performance. Procedia - Social and Behavioral Sciences 66, 555 - 563

Moreillon, Judi. 2007. Collaborative Strategies for Teaching Reading Comprehension. Chicago: American Library Association.

Murray. (1980). The effect of two techniques which elicit productive response on the comprehension of content area reading materials. Unpublished MA dissertation. The University of Connecticut.

Nahid, S \& Zahra Kafi. (2014). On the Effect of Playing Digital Games on Iranian Intermediate EFL Learners' Motivation toward Learning English Vocabularies. Iran: Azad University.

Nation, I. S. P. (1990). Teaching and learning vocabulary. New York: Newbury House.

Nation, I. S. P. (2001). Learning Vocabulary in Another Language. Cambridge: Cambridge University Press.

Nguyen. T.T.T. (2012). The Impact of Background Knowledge and Time Constraint on Reading Comprehension of Vietnamese Learners of English as a Second Language. PhD thesis, Southern Illinois University Carbondale

Nunnan, David. (1991). Language Teaching Methodology. New York: Practice Hall

Novita, Dewi. (2018). An Analysis On The Students' Vocabulary Mastery A Descriptive Study on the MTS. Untan Journal vol. 9 
Okta. (2015). The Effect of Word Knowledge Framework on Students' Vocabulary Mastery at SMP 25 Pekanbaru. Pekanbaru: Islamic University of Riau

Pulido, D. (2007). The relationship between text comprehension and second language incidental vocabulary acquisition: A matter of topic familiarity? Language Learning, 57(1), 155-199

Qian, D.D. (2002). Investigating the relationship between vocabulary knowledge and academic reading performance: an assessment perspective. Language Learning 52(3), 513-536.

Qteefan, Ghosoon. (2012). The Effectiveness of Using Educational Computer Games Developing Palestinian Fifth Graders" Achievement in English Language in Gaza Governorate. Thesis.

Ratih, Sujayanti. (2017). Improving grade VIII Students' Vocabulary Mastery Through The Concept Attainment Model Mts. Alwasliyah Tembung in 2016/2017. Academic Year. Thesis: Uin Sumatra Utara.

Read, J. (2000). Assessing vocabulary. Cambridge, England: Cambridge University Press.

Reeve, Jhonmarshall. (1997). Expresing Instrinsic Motivation Through Acts of Explpration and Facial Display of Interest. Pleanum Publishing Corporation. Vol 21, No 3

Richards, J. (1976). The role of vocabulary teaching. TESOL Quarterly, 10(1), 77-90.

Ricketts, J., Nation, K. \& Bishop, D. (2007). Vocabulary is important for some, but not all reading skills. Scientific Studies of Reading, 11(3), 235-257.

Salah, S. M. (2008). The Relationship between Vocabulary Knowledge and Reading Comprehension of Authentic Arabic Texts. Brigham Young University.

Schulman, L. (1999). Taking learning seriously",.Change Journal, 31(4), , p. 12, http://www.guide linesonlearning.com/guideline-five (Retrieved on April 27th2013).

Shen, Zhifa. (2013). The Effects of Vocabulary Knowledge and Dictionary Use on EFL Reading Performance. Canadian Center of Science Education. Vol. 6, No.6.

Snow, C. (2002). Reading for Understanding: Toward an ReD Program in Reading Comprehension. Santa Monica: The RAND Corporation.

Stahl, S.(2003). Vocabulary and readability: how knowing word meanings affects comprehension. Topics in Language Disorders, 23(3), 241-247.

Slavin, R.V (2009) Educational of Pyschology theory and Practice. Usa: Pearson

Steven, K. C. The Effect of Bcakground Knowledge on the Reading Comprehension of Ninth Graders. Journal of Reading behavior. 12 (2)

Steven. (1980). Prior Knowledge: Curriculum Enhanment: Report National Center on Accessing the General Curriculum (NCAC).

Suri, Martha (2012). Improving Students' Vocabulary Mastery by Using Songs at The sixth pf StateElementry School of 45 Bungo pasang Pandang, Edu Research.Jurnal Pendidikan Vol.1 No.1 2012.

Sze, Lui. (2012). Use of Gamification In Vocabulary Learning : A Case Study in Maccau. Macau: University of Macau

Thornbury, Scott. (2002). How to Teach Vocabulary. England : Pearson Education Limited.

Turgut, Irgin. (2009). Young learnerse language learning via computer games. Available at: www.sciencedirect.com

Uma, J. Chitra and A. Ponnambala Thiagarajan. (2001). Teaching Writing Skill Through Silent Movie: An experiment. Indian Journal of Open Learning, 10 (1), 93-99. ISSN 0971-2690. India: Indira Gandhi National Open University. Downloaded on September 2017. 
Wan,Chin \& Chiou, Wen. (2006). Psychological Motivs and Online Games Addiction: A Test of Flow Theory and Humanistic Needs Theory for taiwanese Adilescents. ChyberPsychology \& Behavior. Vol.9

Widjaja, Grace. (2002). Complete English Grammar and the Exercise. Salatiga :Pt Buana Ilmu popular Westwood P. (2008). What teachers need to know about Spelling. ACER Press.

Wright, Jance. (2011) The Effects Of Vidio Game Play on Academic Performance. University if Cumberllands. Vol 17. Pp 37-44

$\mathrm{Xu}$, Zhengchuan. (2011). Online Game Adiction among Adolescents:Motivation and Prevention Factors. Eoropean Journal of Information Systems. Vol.21, 321-340.

Yen, chen. (2017). Empirical Study On The Effect Of Digital Game-Based Instruction On Students' Learing Motivation And Achievment. EURASIA Journal of Mathmatics Science And Technology Education, 10.12973. ISSN 1305-8223. Taiwan:Far East University. Downloaded on September 2017. 